\title{
Enzymes involved in phenylalanine metabolism in the human foetus and child
}

\author{
ANNE McLEAN, MARGARET J. MARWICK, AND BARBARA E. CLAYTON \\ From the Department of Chemical Pathology, The Hospital for Sick Children, Great Ormond Street, and \\ Institute of Child Health, Guilford Street, London
}

SYNOPSIS The activities of phenylalanine p-hydroxylase, tyrosine : alpha-ketoglutarate and $\overline{\bar{O}}$ phenylalanine : pyruvate aminotransferases, and aromatic alpha-ketoacid reductase have been $\tilde{\sigma}_{\Omega}$ measured in liver biopsies obtained from children with a series of disorders other than phenylketonuria. 0 and from human foetuses aged 8.5 to 24 weeks. The importance of such a study in relation to the management of infants with hyperphenylalaninaemia and pregnant phenylketonuric women is $\circ$ discussed

In classical phenylketonuria, the absence of liver phenylalanine (Phe) p-hydroxylase results in a high level of Phe in the blood and excretion of abnormal aromatic acid metabolites in the urine (seefig). Unless treated from early infancy by a low Phe diet, progressive intellectual deterioration usually occurs. With the introduction of more sensitive screening procedures (Medical Research Council working party on phenylketonuria, 1968), not only are infants with classical phenylketonuria detected, but also a whole spectrum of children with hyperphenylalaninaemia, the significance of which is largely unknown (Bickel, 1970). This raises many problems, including whether or not dietary treatment should be used in these atypical patients.

Children born to women with untreated phenylketonuria frequently have multiple abnormalities including severe mental retardation $(\mathrm{Yu}$ and O'Halloran, 1970), even though they do not have phenylketonuria. With successful treatment, affected girls of normal intelligence are just reaching the age of marriage, and they will require dietary treatment during pregnancy in an attempt to protect the foetus from high levels of Phe and its metabolites in the maternal circulation. Since Phe deficiency of itself is harmful and can cause brain damage, dietary treatment presents problems (Pitt, 1967).

With these considerations in mind, a more detailed knowledge of the metabolism of Phe both in children and in the human foetus would appear essential to a fuller understanding of the problems involved. Only a few assays on Phe p-hydroxylase and the pteridine cofactor in the human subject

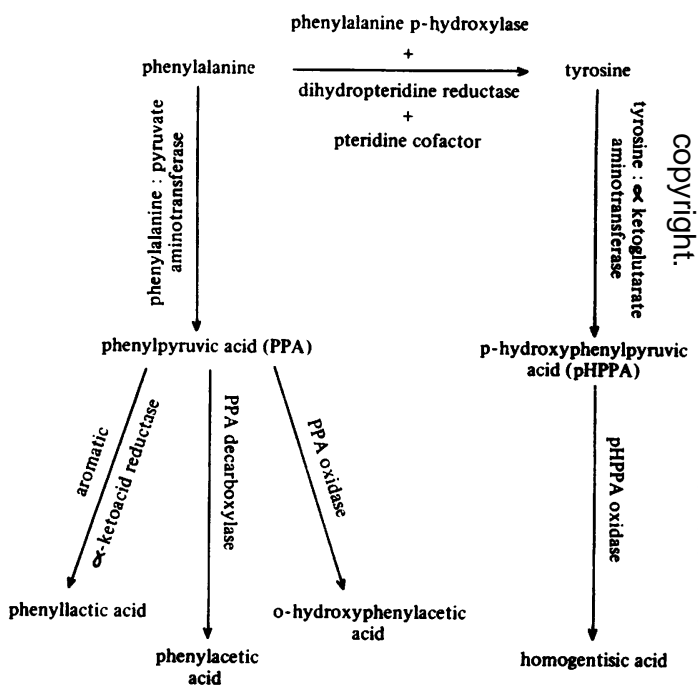

Fig Enzymes involved in the metabolism of phenylalanine.

(Kaufman, 1958; Justice, O'Flynn, and Hsia, 1967; Jakubovič, 1971) are available. The work presented N here has established a range of values in children without phenylketonuria and in the human foetus $N$ for Phe p-hydroxylase, tyrosine : alpha-ketoglutarate $\underset{\omega}{\omega}$ and Phe : pyruvate aminotransferases and aromatic $\sigma$ alpha-ketoacid reductase (see fig).

\section{Materials}

Liver was obtained from children when a biopsy was being taken for diagnostic purposes. None of them 
had phenylketonuria but they had a variety of disorders as shown in table II.

Foetal livers from therapeutic abortions were provided by the Foetal Tissue Bank, Royal Marsden Hospital, London.

3', 5'-Diiodo-p-hydroxyphenylpyruvic acid was obtained from Calbiochem Ltd, Los Angeles, California 90054, USA, all other substrates and coenzymes from British Drug Houses Ltd, Poole, Dorset.

\section{Methods and Results}

\section{PROTEIN ESTIMATIONS}

These were performed by the biuret method on a Technicon AutoAnalyzer.

\section{TREATMENT OF LIVER BIOPSIES}

After excision all liver specimens from children were frozen immediately in liquid nitrogen, liquid nheptane, or a solid carbon dioxide-acetone mixture and stored at $-70^{\circ} \mathrm{C}$. Foetal livers were usually excised within one hour of death, during which time they were maintained at $+4^{\circ} \mathrm{C}$.

Since Phe p-hydroxylase activity appeared to deteriorate after two or three weeks' storage, this was always measured within one week of collection. All other enzymes investigated were stable for six months to one year (table I).

\begin{tabular}{|c|c|c|c|}
\hline Enzyme & Patient & Activity & $\begin{array}{l}\text { Length of } \\
\text { Storage }\end{array}$ \\
\hline $\begin{array}{l}\text { Phenylalanine p-hydroxylase } \\
\text { ( } \mu \text { mole tyrosine/hr/g protein) }\end{array}$ & $\begin{array}{l}\text { T.H. } \\
\text { A.J. } \\
\text { S.J. }\end{array}$ & $\begin{array}{l}37 \\
36 \cdot 5 \\
31 \\
23 \cdot 5 \\
21 \\
\text { None detected } \\
15 \cdot 6 \\
13 \cdot 1 \\
8 \cdot 8\end{array}$ & $\begin{array}{l}1 \text { day } \\
2 \text { wk } \\
4 \text { wk } \\
1 \text { day } \\
1 \text { wk } \\
6 \text { mth } \\
1 \text { day } \\
1 \text { wk } \\
3 \text { wk }\end{array}$ \\
\hline $\begin{array}{l}\text { Tyrosine : alpha-ketoglutarate } \\
\text { amino-transferase ( } \mu \text { mole } \\
\text { pHPPA/min } / g \text { protein })\end{array}$ & $\begin{array}{l}\text { S.J. } \\
\text { D.C. }\end{array}$ & $\begin{array}{l}85 \\
80 \cdot 8 \\
85 \cdot 5 \\
81 \\
80 \cdot 5\end{array}$ & $\begin{array}{l}2 \text { days } \\
6 \text { mth } \\
1 \text { day } \\
3 \text { mth } \\
7 \mathrm{mth}\end{array}$ \\
\hline $\begin{array}{l}\text { Aromatic alpha-ketoacid } \\
\text { reductase (units/g protein) }\end{array}$ & $\begin{array}{l}\text { A. J. } \\
\text { S.J. }\end{array}$ & $\begin{array}{r}1250 \\
1220 \\
1205 \\
805 \\
825 \\
790\end{array}$ & $\begin{array}{c}3 \mathrm{wk} \\
3 \mathrm{mth} \\
10 \mathrm{mth} \\
1 \mathrm{wk} \\
2 \mathrm{mth} \\
7 \mathrm{mth}\end{array}$ \\
\hline $\begin{array}{l}\text { Phenylalanine : pyruvate amino- } \\
\text { transferase ( } \mu \text { mole PPA } / 10 \mathrm{~min} / \\
\text { g protein) }\end{array}$ & $\begin{array}{l}\text { D.C. } \\
\text { C.O. } \\
\text { A.F. }\end{array}$ & $\begin{array}{c}110 \\
122 \\
105 \\
286 \\
275 \\
268 \\
55 \cdot 2 \\
58 \\
51 \cdot 5\end{array}$ & $\begin{array}{c}3 \mathrm{wk} \\
1 \mathrm{mth} \\
10 \mathrm{mth} \\
1 \mathrm{mth} \\
4 \mathrm{mth} \\
1 \mathrm{yr} \\
1 \mathrm{wk} \\
3 \mathrm{wk} \\
7 \mathrm{mth}\end{array}$ \\
\hline
\end{tabular}

Table I Stability of enzymes on storage at $-70^{\circ} \mathrm{C}$
PHENYLALANINE P-HYDROXYLASE ACTIVITY Livers were hand-homogenized in small glass tissue grinders in 4 volumes cold $0.15 \mathrm{M}$-potassium chloride and centrifuged at $16000 \mathrm{~g}$ for $15 \mathrm{~min}$ at $0^{\circ} \mathrm{C}$. In preliminary studies assays were performed on both untreated and treated homogenate. In the latter instance $250 \mu$ l of homogenate was passed through a Sephadex G- 100 column ( $3 \mathrm{~cm}$ long, $0.5 \mathrm{~cm}$ diameter) equilibrated with $0.15 \mathrm{M}-\mathrm{KCl}$ and eluted with the same solution to remove cofactors for other possible interfering reactions. Since assays employing the resulting homogenate gave activities varying less than $10 \%$ from those employing the untreated homogenate, the latter was used as a standard homogenate throughout the study. The incubation mixture was adapted from Justice et al (1967) and contained L-phenylalanine (1.0 $\mu$ mole), NADH ( $1.25 \mu$ mole), nicotinamide $(2.5 \mu$ mole $)$, dimethyltetrahydro-pteridine $(1 \cdot 15 \mu \mathrm{mole})$, and liver homogenate $(50 \mu \mathrm{l})$. The final volume was made up to $0.8 \mathrm{ml}$ with $0.2 \mathrm{M}$ -

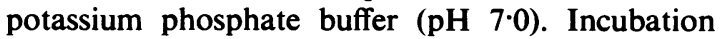
times used were $30 \mathrm{~min}$ and $60 \mathrm{~min}$ at $37^{\circ} \mathrm{C}$. Liver homogenate was omitted from the control tube, and an additional tube containing no dimethyltetrahydro-pteridine (DMTHP) cofactor was included. The reaction was terminated by the addition of 0.8 $\mathrm{ml} \mathrm{30 \% (wt/v)} \mathrm{trichloracetic} \mathrm{acid.} \mathrm{Standards} \mathrm{con-}$ taining 0.025 to $0.2 \mu$ mole tyrosine in $0.8 \mathrm{ml}$ water were treated in the same way. The mixtures were diluted to $4 \mathrm{ml}$ with water and centrifuged. Tyrosine was determined in the supernatants $(0.5 \mathrm{ml}$ aliquots) by the method of Udenfriend and Cooper (1952) using $0.25 \mathrm{ml}$ each of $0.1 \%$ (wt/v) 1-nitroso-2naphthol in $95 \%$ ethanol and $0.05 \%$ (wt/v) sodium nitrite in 2.66 $\mathrm{N}$ nitric acid. After incubating at $55^{\circ} \mathrm{C}$ for $30 \mathrm{~min}$ and cooling $1 \mathrm{ml}$ water and $2.5 \mathrm{ml}$ 1,2-dichloromethane were added. After mixing the tubes on a Vortex for $15 \mathrm{sec}$ the upper aqueous layers were taken off and read in an Aminco SPF 125 fluorimeter at an excitation wavelength of $445 \mathrm{~m} \mu$ and an emission wavelength of $555 \mathrm{~m} \mu$.

TYROSINE : ALPHA-KETOGLUTARATE AMINOTRANSFERASE ACTIVITY

The method of preparing the homogenate was the same as that used for the Phe p-hydroxylase assay; it was convenient to prepare sufficient homogenate for use in both assays and a portion was stored for 24 hours exactly at $4^{\circ} \mathrm{C}$ before being used in this assay. This treatment resulted in the loss of most of the p-hydroxyphenylpyruvate oxidase. Inclusion of the diethyldithiocarbamate as an inhibitor of p-hydroxyphenylpyruvate oxidase in fresh preparations, or treatment with Sephadex G-100 as described above, gave activities varying less than $14 \%$ from those using aged preparations. The latter method was 
therefore employed as the standard one, since the use of diethyldithiocarbamate frequently caused excessively high optical densities (as previously reported by Diamondstone, 1966). The incubation mixtures (three tubes) contained liver homogenate $(10 \mu \mathrm{l})$, L-tyrosine ( $2 \mu$ mole), and pyridoxal phosphate $(0.012 \mu \mathrm{mole})$ in a total volume of $330 \mu \mathrm{l} 0.2 \mathrm{M}$ potassium phosphate buffer $(\mathrm{pH} \mathrm{7 \cdot 3)}$. These were preincubated for one hour at $37^{\circ} \mathrm{C} .10 \mathrm{~N}$-sodium hydroxide $(20 \mu \mathrm{l})$ was then added to the control tube, followed by alpha-ketoglutarate $(3 \mu$ mole in $10 \mu \mathrm{l}$

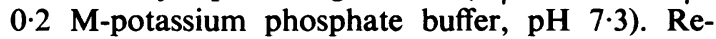
actions in the remaining two tubes, after the addition of $10 \mu \mathrm{l}$ alpha-ketoglutarate solution, were terminated after 10 and $20 \mathrm{~min}$ by the addition of $20 \mu \mathrm{l} 10$ $\mathrm{N}$-sodium hydroxide. It was very important to mix the tubes thoroughly immediately after the addition of sodium hydroxide. The optical densities of the mixtures were read at $331 \mathrm{~m} \mu 25 \mathrm{~min}$ after the addi- tion of sodium hydroxide. Standard mixtures of p-hydroxyphenylpyruvic acid (pHPPA, 0.05-0.25으 $\mu$ mole in $340 \mu \mathrm{l} 0 \cdot 2 \mathrm{M}$-potassium phosphate buffer, $\Rightarrow$ pH 7.3) were treated with $20 \mu \mathrm{l} 10 \mathrm{~N}$-sodium $\stackrel{\text { ? }}{9}$ hydroxide and read in the same way.

\section{PHENYLALANINE : PYRUVATE AMINOTRANS- FERASE ACTIVITY}

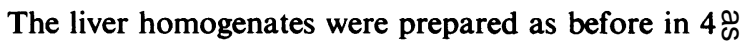
volumes cold $\mathbf{0} \cdot 15 \mathrm{M}$-potassium chloride and $\vec{\circ}$ centrifuged at $30000 \mathrm{~g}$ for 30 minutes. Use of $\rightarrow$ homogenates treated with Sephadex G-100 as $\vec{\omega}$ described under phenylalanine hydroxylase gave results varying less than $15 \%$ from those using untreated homogenates. The latter was therefore on used in the standard procedure. The incubation 0 mixtures (three tubes) consisted of liver homogenate $(20 \mu \mathrm{l}), \mathrm{L}-$ phenylalanine $(2 \cdot 14 \mu \mathrm{mole})$, and pyridoxal $\infty$ phosphate $(0.012 \mu \mathrm{mole})$ in a total volume of $320 \mu \mathrm{l}$ 오

\begin{tabular}{|c|c|c|c|c|c|c|c|}
\hline Patient & Age & Diagnosis & $\begin{array}{l}\text { Phe p-Hydroxylase } \\
\text { (umole tyrosine } / \mathrm{hr} / \mathrm{g} \\
\text { protein) }\end{array}$ & $\begin{array}{l}\text { Tyrosine Amino- } \\
\text { transferase (umole } \\
\text { phPPA/min } / g \\
\text { protein) }\end{array}$ & $\begin{array}{l}\text { Aromatic Alpha- } \\
\text { ketoacid Reductase } \\
\text { (units/g protein) }\end{array}$ & $\begin{array}{l}\text { Phe Aminotransferase } \\
\text { ( } \mu \text { mole PPA } / 10 \mathrm{~min} / \mathrm{g} \\
\text { protein) }\end{array}$ & $\frac{\frac{0}{D}}{\frac{D}{O}}$ \\
\hline \multicolumn{7}{|l|}{ Males } & \\
\hline G.S. & 4 wk & $\begin{array}{l}\text { Septicaemia and liver } \\
\text { abscess }\end{array}$ & $15 \cdot 4$ & $47 \cdot 6$ & 1310 & 24 & \\
\hline A.F. & 6 wk & Obstructive jaundice & 18 & $45 \cdot 3$ & 910 & $55 \cdot 2$ & $\leq$ \\
\hline J.L. & 7 wk & Biliary atresia & $21 \cdot 5$ & 81 & 955 & 73 & 2. \\
\hline I.G. & 8 wk & Giant cell hepatitis & $28 \cdot 4$ & 56 & 970 & 68 & $\bar{z}$ \\
\hline R.L. & 8 wk & Biliary atresia & $13 \cdot 1$ & 79 & 2150 & 262 & $\supseteqq$ \\
\hline S.T. & 8 wk & Biliary atresia & $15 \cdot 7$ & $57 \cdot 5$ & 780 & $53 \cdot 5$ & $\overline{\mathrm{O}}$ \\
\hline S.J. & $3 \mathrm{mth}$ & Biliary atresia & $15 \cdot 6$ & 85 & 805 & 230 & బి \\
\hline D.B. & $3 \mathrm{mth}$ & $\begin{array}{l}\text { Hepatitis; lactose } \\
\text { intolerance }\end{array}$ & $24 \cdot 5$ & 118 & 1218 & $54 \cdot 5$ & อุ \\
\hline E.M. & $3 \mathrm{mth}$ & Biliary atresia & $18 \cdot 5$ & $40 \cdot 7$ & 1310 & $67 \cdot 5$ & \\
\hline J.L. & $7 \mathrm{mth}$ & $\begin{array}{l}\text { Histiocytotic infiltration } \\
\text { of liver and lymph nodes }\end{array}$ & $39 \cdot 3$ & $65 \cdot 5$ & 1440 & 300 & \\
\hline M.S. & $11 \mathrm{mth}$ & Abdominal cyst & $37 \cdot 5$ & 200 & 1295 & $86 \cdot 5$ & $\underset{巳}{\beth}$ \\
\hline A.J. & $14 \mathrm{mth}$ & Glycogen storage disease & $23 \cdot 5$ & $44 \cdot 3$ & 1250 & 104 & \\
\hline D.L. & $22 \mathrm{mth}$ & Hepatosplenomegaly & 53 & 103 & 1240 & 106 & $\because$ \\
\hline M.G. & $2 \mathrm{yr}$ & Appendicectomy & 30 & $27 \cdot 5$ & - & - & $\widehat{\Omega}$ \\
\hline D.B. & $6.5 \mathrm{yr}$ & $\begin{array}{l}\text { Lymphocytosis and } \\
\text { splenomegaly }\end{array}$ & $6 \cdot 7$ & 189 & 560 & 63 & \\
\hline D.C. & $11 \mathrm{yr}$ & Colon resection & 70 & $85 \cdot 5$ & 2270 & 110 & ב \\
\hline C.O. & $12 \mathrm{yr}$ & $\begin{array}{l}\text { Portal hypertension; } \\
\text { splenorenal shunt }\end{array}$ & $48 \cdot 5$ & 222 & 1010 & 286 & \\
\hline \multicolumn{3}{|c|}{ Mean activity \pm standard deviation } & $28 \cdot 2 \pm 16 \cdot 6$ & $91 \pm 58 \cdot 9$ & $1220 \pm 456$ & $121 \cdot 5 \pm 92$ & \\
\hline \multicolumn{7}{|c|}{ Females } & \\
\hline T.H. & 8 wk & Biliary atresia & 37 & 87 & 1780 & $74 \cdot 5$ & \\
\hline $\begin{array}{l}\text { A.T. } \\
\text { K.F. }\end{array}$ & $\begin{array}{l}2.5 \mathrm{mth} \\
3 \mathrm{mth}\end{array}$ & $\begin{array}{l}\text { Biliary atresia } \\
\text { Giant cell hepatitis }\end{array}$ & $\begin{array}{l}60 \\
17 \cdot 4\end{array}$ & $\begin{array}{l}153 \\
22 \cdot 3\end{array}$ & $\begin{array}{l}1450 \\
1930\end{array}$ & $\begin{array}{l}50 \\
51\end{array}$ & $\frac{1}{0}$ \\
\hline T.W. & $3 \mathrm{mth}$ & Biliary atresia & $39 \cdot 5$ & 183 & 1890 & 109 & \\
\hline R.S. & $5 \mathrm{mth}$ & $\begin{array}{l}\text { Adrenal neuroblastoma } \\
\text { with secondary liver } \\
\text { deposits }\end{array}$ & $21 \cdot 5$ & 78 & 1300 & 50 & ת \\
\hline C.S. & $10 \mathrm{mth}$ & Neonatal hepatitis & 34 & 138 & 988 & 152 & \\
\hline M.K. & $2.5 \mathrm{yr}$ & $\begin{array}{l}\text { Biliary atresia and } \\
\text { cirrhosis of liver }\end{array}$ & $21 \cdot 3$ & 47 & - & - & \\
\hline D.F. & $2.5 \mathrm{yr}$ & $\begin{array}{l}\text { Recurrent hepatitis; bile } \\
\text { duct sphinctoplasty }\end{array}$ & $19 \cdot 3$ & 82 & 620 & $78 \cdot 5$ & ع \\
\hline E.M. & $7 \mathrm{yr}$ & $\begin{array}{l}\text { Thalassaemia major and } \\
\text { splenomegaly }\end{array}$ & $22 \cdot 8$ & $41 \cdot 5$ & 1140 & 53 & \\
\hline \multicolumn{3}{|c|}{ Mean activity \pm standard deviation } & $30 \cdot 3 \pm 13.8$ & $92 \cdot 4 \pm 54 \cdot 6$ & $1387 \pm 466$ & $77 \pm 36.6$ & \\
\hline
\end{tabular}

Table $1 \mathrm{I}$ Enzyme activities in children without phenylketonuria

- indicates no estimation performed. 


\begin{tabular}{|c|c|c|c|c|}
\hline Age (weeks) & $\begin{array}{l}\text { Phenylalanine p-Hy- } \\
\text { droxylase ( } \mathrm{Hmole} \\
\text { tyrosine/hr/g protein) }\end{array}$ & $\begin{array}{l}\text { Tyrosine : Alpha- } \\
\text { ketoglutarate Amino- } \\
\text { transferase (umole } \\
\text { pHPPA/min/g protein) }\end{array}$ & $\begin{array}{l}\text { Aromatic Alpha- } \\
\text { ketoacid Reductase } \\
\text { (units/g protein) }\end{array}$ & $\begin{array}{l}\text { Phenylalanine : Pyruvate } \\
\text { Aminotransferase } \\
\text { ( } \text { mole PPA } / 10 \mathrm{~min} / \mathrm{s} \\
\text { protein) }\end{array}$ \\
\hline \multicolumn{5}{|l|}{ Male } \\
\hline 125 & $25 \cdot 8$ & $7 \cdot 5$ & 780 & $36 \cdot 3$ \\
\hline 14 & 11.4 & 2.85 & 895 & $34 \cdot 6$ \\
\hline 14 & 22 & $5 \cdot 4$ & 780 & $10 \cdot 3$ \\
\hline 15 & $28 \cdot 8$ & $10 \cdot 3$ & - & - \\
\hline 18 & 20 & 8.4 & 910 & - \\
\hline 21 & $8 \cdot 3$ & $11 \cdot 7$ & 1170 & $20 \cdot 8$ \\
\hline 22 & $10 \cdot 8$ & $9 \cdot 6$ & 1055 & 15 \\
\hline 24 & 1.67 & $6 \cdot 7$ & 843 & $14 \cdot 2$ \\
\hline Mean activity \pm standard deviation & $16 \pm 9 \cdot 4$ & $7 \cdot 8 \pm 2 \cdot 8$ & $919 \pm 145$ & $22 \pm 11$ \\
\hline \multicolumn{5}{|l|}{ Female } \\
\hline $8 \cdot 5$ & $15 \cdot 8$ & - & - & - \\
\hline 10 & $16 \cdot 6$ & $3 \cdot 3$ & 497 & $31 \cdot 2$ \\
\hline $14 \cdot 5$ & 6.8 & $9 \cdot 7$ & 865 & $12 \cdot 1$ \\
\hline 15 & 8.95 & 6.9 & 763 & 7.9 \\
\hline 16 & $5 \cdot 2$ & $24 \cdot 5$ & - & - \\
\hline 17 & $13 \cdot 3$ & $11 \cdot 6$ & 910 & $43 \cdot 5$ \\
\hline 18 & 12 & 6 & 890 & 30 \\
\hline 18 & $20 \cdot 8$ & $12 \cdot 1$ & 760 & $27 \cdot 8$ \\
\hline 18 & 21.7 & 7.6 & 1150 & 40 \\
\hline 19 & $18 \cdot 7$ & $7 \cdot 5$ & - & - \\
\hline 20 & $10 \cdot 3$ & 7.9 & 405 & - \\
\hline 20 & $10 \cdot 3$ & 7 & 401 & $41 \cdot 5$ \\
\hline Mean activity \pm standard deviation & $13.4 \pm 5.4$ & $9 \cdot 5 \pm 5 \cdot 3$ & $738 \pm 256$ & $29 \cdot 2+17 \cdot 5$ \\
\hline
\end{tabular}

Table III Enzyme activities in human foetal livers

— indicates no estimation performed

0.2 M-potassium phosphate buffer ( $\mathrm{pH} 7 \cdot 7$ ). These were preincubated at $37^{\circ} \mathrm{C}$ for one hour. Ten $\mathrm{N}$-sodium hydroxide $(20 \mu \mathrm{l})$ was then added to the control tube, followed by pyruvate $(3 \mu$ mole in $10 \mu \mathrm{l} 0.2$ M-potassium phosphate buffer, $\mathrm{pH}$ 7.7). The remaining two tubes, after the addition of $10 \mu \mathrm{l}$ pyruvate solution, were incubated at $37^{\circ} \mathrm{C}$ for 20 and $40 \mathrm{~min}$, the reaction being terminated by the addition of $20 \mu \mathrm{l} 10 \mathrm{~N}$-sodium hydroxide. It was very important to mix the tubes thoroughly immediately after the addition of sodium hydroxide. The optical densities of the mixtures were read at $315 \mathrm{~m} \mu$ within two or three min of the addition of sodium hydroxide. Standard mixtures of phenylpyruvic acid (PPA, 0.05 to $0.5 \mu$ mole in $3.2 \mathrm{ml} \mathrm{0.2} \mathrm{M-potassium}$ phosphate buffer, $\mathrm{pH} 7 \cdot 7$ ) were treated with $200 \mu \mathrm{l}$ $10 \mathrm{~N}$-sodium hydroxide and read in the same way.

\section{AROMATIC ALPHA-KETOACID REDUCTASE}

Livers were homogenized as before and spun at 6000 $g$ for 20 minutes. The method used was adapted from Weber and Zannoni (1966). Use of homogenates treated with Sephadex G-100 as described under phenylalanine hydroxylase gave results varying less than $12 \%$ from those using untreated homogenates. The latter was therefore used in the standard procedure. The reaction mixture (contained in $1 \mathrm{~cm}$ microcuvettes) consisted of liver homogenate $(5 \mu \mathrm{l})$, 0.2 M-potassium phosphate buffer containing 1 mmol EDTA per litre (pH 6.5) $(20 \mu \mathrm{l})$, water $(250$ $\mu l)$, sodium dodecyl sulphate (SDS), (0.001 $\mu$ mole in $1 \mu \mathrm{l})$ and p-chloromercuribenzoate $(0.025 \mu$ mole in $5 \mu \mathrm{l})$. These reagents were mixed and left at $25^{\circ} \mathrm{C}$ for 30 minutes. Then NADH $(0 \cdot 1 \mu$ mole in $10 \mu \mathrm{l})$ and $3^{\prime}, 5^{\prime}$-diiodo pHPPA $(0 \cdot 2 \mu$ mole in $5 \mu \mathrm{l}$ of a solution containing $150 \mathrm{mmol}$ sodium carbonate and 50 mmol sodium bicarbonate per litre) were added to initiate the reaction, and the decrease in optical density followed at $25^{\circ} \mathrm{C}$ at $340 \mathrm{~m} \mu$ for $5 \mathrm{~min}$, readings being taken at 30 -sec intervals. The NADH was omitted from the control solution, and the test solutions were assayed with and without sodium dodecyl sulphate. One unit of activity was defined as the quantity of enzyme causing an optical density decrease of 1 per min under the conditions stated for the assay. The initial rate of decrease of optical density was always used.

\section{AGREEMENT BETWEEN DUPLICATES AND \\ REPRODUCIBILITY OF ASSAYS}

Agreement between duplicates within individual enzyme assays was usually excellent. The variation in the phenylalanine hydroxylase assay was usually nil, but occasionally variations of between 0.1 and 0.5 fluorimeter units were found. These are so small that no significant differences can be deduced from the standard graphs. Duplicates in the tyrosine transaminase assay never varied more than 0.01 optical density units. This produces almost negligible differences in the activity: for example, 11.8 instead 
of $11.6 \mu$ moles pHPPA per min per $\mathrm{g}$ protein in liver from the female foetus aged 17 weeks. Duplicates in the phenylalanine transaminase assay were also excellent except in subjects K.F., R.S., and D.L. where a variation of 0.01 in optical density caused activities to vary from 49 to $53,46 \cdot 5$ to $53 \cdot 5$, and 103 to $109 \mu$ moles PPA per 10 min per $g$ protein respectively. Mean results for these three subjects are given in table II. Since aromatic alpha-ketoacid reductase activities are based on a rate of change of optical density, the occasional optical density value that fell outside the straight line could be ignored, and duplicates were all in good agreement.

Opportunities for studying the reproducibility of enzyme assays over several days were severely limited by the small amount of material available, but some indications that reproducibility was fairly good can be seen in table I, which sets out the activities of some specimens during long periods of storage.

Results of the enzyme assays are set out in tables II and III.

\section{Discussion}

The concentrations of enzymes were similar in male and female foetuses and apart from Phe p-hydroxylase showed no change with age. The results did suggest that Phe p-hydroxylase might decrease in activity as the male foetuses became older, but until more data are available this finding is inconclusive. Whereas the mean activity for Phe p-hydroxylase in children was $29.2 \mu$ mole per hr per $\mathrm{g}$ protein, it was only 14.7 in the foetal liver. Low activity of Phe p-hydroxylase was observed by Jakubovič (1971) in the livers of seven human foetuses aged 11 to 20 weeks, but though both cofactor and reductase were demonstrated no detailed investigations were performed and no adult tissues were included for comparison. There exists, therefore, a diminished but still fairly active system for the conversion of Phe to tyrosine in the foetus. The system is a complex one involving a pteridine cofactor and dihydropteridine reductase, in addition to the Phe p-hydroxylase. The cofactor and dihydropteridine reductase were measured in foetal rat liver by Brenneman and Kaufman (1965), who found less activity than in the adult rat, whereas the hydroxylase activity was not diminished at all. Although Kenney and Kretchmer (1959) reported that the cofactor and dihydropteridine reductase were present in the foetal rat, they found that Phe p-hydroxylase activity was somewhat lower than in the adult. Recent work by McGee, Greengard, and Knox (1972) supports the latter finding. We are now studying the activities of the cofactor and dihydropteridine reductase in human liver, and the additional data should give a clearer $\frac{0}{\tilde{\sigma}}$ picture of the foetal enzyme system in man.

The activities of the two aminotransferases, $\overrightarrow{\vec{F}}$ particularly the tyrosine : alpha-ketoglutarate? enzyme, were much lower in the foetus than in the $\frac{\mathrm{C}}{\mathrm{O}}$ child. It has been known for some time that amino $\frac{\bar{\sigma}}{\overline{5}}$ acid concentrations in the foetal liver (Ryan and $\vec{\nabla}$

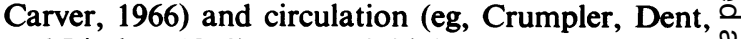
and Lindan, 1950) are much higher than those in the of maternal liver and circulation and this could well be $\overrightarrow{0}$ a reflection of the relative inability of the foetal amino-transferases to metabolize the amino acids $\vec{\omega}$ further. Foetal rat liver is also deficient in tyrosine $\frac{\Omega}{0}$ aminotransferase activity (Sereni, Kenney, and Kretchmer, 1959). It is possible that a number of the $N$ other aminotransferases in foetal liver are also 0 somewhat inactive, although the tyrosine enzyme $\underset{\infty}{\infty}$ does appear to be particularly late maturing. Our ${ }_{0}^{\infty}$ results suggest that dietary control of the intake during pregnancy in the woman with phenylketonuria $\vec{A}$ will have to be strict if high levels of Phe in the foetus $\mathbb{D}$ are to be avoided.

Four of the boys (R.L., S.J., J.L., and C.O.) had very high phenylalanine aminotransferase activities $\stackrel{\Phi}{-}$ and of these C.O. also had an abnormally raised $\vec{\varphi}$ tyrosine aminotransferase activity. Since R.L., S..$\widehat{乛}$ and C.O. also had very high serum GOT and GPF activities, these phenylalanine aminotransferasse. activities should probably not be regarded as normat: If these four values are omitted from the calculation of the mean activity, it becomes $68 \pm 40 \mu$ mole per $\stackrel{2}{\circ}$ $10 \mathrm{~min}$ per $\mathrm{g}$ protein which corresponds more $\cong$ closely with that of $77 \pm 36.6$ obtained for the livers from girls.

Neither the present study nor the reported work of Weber and Zannoni $(1966,1968)$ have elucidated the reason for the non-linearity of the change of substrate concentration with time in the assay for aromatic alpha-ketoacid reductase. The activities in the present work are based, as are those of Weber and Zannoni (1966) on the initial rate of disappear- 3 ance of NADH. The results show that the enzyme is 0 quite active in the foetus (about $65 \%$ of the activity in the child) unlike the activities of the two transaminases.

This study has provided values for some liver N enzymes involved in the metabolism of Phe by the $N$ foetus and the child. It suffers from the inevitable N limitation that all the children were ill and liver $\mathcal{O}$ biopsy was performed for this reason, but none of them had phenylketonuria and the data provide $\stackrel{\varrho}{\square}$ more valid reference values than would be obtained $\stackrel{\infty}{\infty}$ from studies in animals. Such information may eventually help to elucidate those patients at present considered to have 'hyperphenylalaninaemia' or 'atypical' phenylketonuria. 
We thank Mr H. H. Nixon, consultant surgeon at The Hospital for Sick Children, and Dr H. E. M. Kay, Director of the Foetal Tissue Bank at the Royal Marsden Hospital, for their kind cooperation in providing liver specimens. Financial support is gratefully acknowledged from the Wellcome Trust and from the Department of Health and Social Security under the scheme for locally organized clinical research. We are grateful to Dr B. P. Tong for gifts of chemicals.

\section{References}

Bickel, H. (1970). Phenylalaninaemia or classical phenylketonuria (PKU)? Neuropädiatrie, 1, 379-382.

Brenneman, A. R., and Kaufman, S. (1965). Characteristics of the hepatic phenylalanine-hydroxylating system in newborn rats. J. biol. Chem., 240, 3617-3622.

Crumpler, H. R., Dent, C. E., and Lindan, O. (1950). The amino acid pattern in human foetal and maternal plasma at delivery. Biochem. J., 47, 223-227.

Diamondstone, T. I. (1966). Assay of tyrosine transaminase activity by conversion of p-hydroxyphenylpyruvate to p-hydroxybenzaldehyde. Analyt. Biochem., 16, 395-401.

Jakubovic, A. (1971). Phenylalanine-hydroxylating system in the human fetus at different developmental ages. Biochim. biophys. Acta (Amst.), 237, 469-475.
Justice, P., O'Flynn, M. E., and Hsia, D. Y. (1967). Phenylalanine hydroxylase activity in hyperphenylaninaemia. Lancet, 1, 928-929.

Kaufman, S. (1958). Phenylalanine hydroxylation cofactor in phenylketonuria. Science, 128, 1506-1507.

Kenney, F. T., and Kretchmer, N. (1959). Hepatic metabolism of phenylalanine during development. J. clin. Invest., 38, 21892196.

McGee, M. M., Greengard, O., and Knox, W. E. (1972). The quantitative determination of phenylalanine hydroxylase in rat tissues. Its developmental formation in the liver. Biochem. J., 127, 669-674.

Medical Research Council working party on phenylketonuria (1968). Present status of different mass screening procedures for phenylketonuria. Brit. med. J., 4, 7-13.

Pitt, D. (1967). Phenylalanine maintenance in phenylketonuria. Aust. Paediat. J., 3, 161-163.

Ryan, W. L., and Carver, M. J. (1966). Free amino acids of human foetal and adult liver. Nature (Lond.), 212, 292-293.

Sereni, F., Kenney, F. T., and Kretchmer, N. (1959). Factors influencing the development of tyrosine-a-ketoglutarate transaminase activity in rat liver. J. biol. Chem., 234, 609-612.

Udenfriend, S., and Cooper, J. R. (1952). The chemical estimation of tyrosine and tyramine. J. biol. Chem., 196, 227-233.

Weber, W. W., and Zannoni, V. G. (1966). Reduction of phenylpyruvic acids to phenyllactic acids in mammalian tissues. $J$. biol. Chem., 241, 1345-1349.

Weber, W. W., and Zannoni, V. G. (1968). Reduction of aromatic a-keto acids by lactic dehydrogenase isozymes and aromatic a-keto acid reductase. Ann. N.Y. Acad. Sci., 151, 627-637.

Yu, J. S., and O'Halloran, M. T. (1970). Children of mothers with phenylketonuria. Lancet, 1, 210-212. 